\title{
PENGARUH STRATEGI PEMBELAJARAN KOOPERATIF JIGSA W DAN KETERAMPILAN SOSIAL TERHADAP HASIL BELAJAR IPS DI SDN KABUPATEN BANGKALAN
}

\author{
Abdul Wahid \\ Jl. Kh. Ach. Munif No: 44 Burneh Bangkalan \\ wahidabdul2201@gmail.com
}

\begin{abstract}
Abstrak: Pembelajaran yang baik merupakan perwujudan dari ketepatan penerapan teknologi pembelajaran yang memungkinkan proses pembelajaran berlangsung secara baik agar mencapai tujuan (efektif) dan dengan biaya yang lebih murah (efisien). Pembelajaran kooperatif jigsaw dipandang lebih baik dari pada pembelajaran secara individu, maupun pembelajaran yang bersifat kompetitif. Hasil statistik deskriptif menunjukkan bahwa hasil strategi pembelajaran jigsaw memberikan pengaruh yang lebih tinggi dibandingkan tradisional. Penelitian ini menggunakan rancangan dengan desain faktorial non-equivalent control group design, yang dilaksanakan pada 4 (empat) kelas paralel di kelas V di 2 (dua) Sekolah Dasar, dengan jumlah siswa keseluruhan 134 orang dan yang diambil sebagai subjek penelitian adalah 120 orang. Teknik pemilihan kelas penelitian dilakukan dengan pengundian 4 (empat) kelas yang ada. Dua kelas diundi sebagai kelas eksperimen, sedangkan 2 (dua) kelas lainnya terpilih sebagai kelas kontrol. Untuk analisis data menggunakan ANOVA faktorial $2 \times 2$ (Anova dua jalur) dengan mempergunakan program SPSS 16. Hasil penelitian adalah: 1) terdapat perbedaan hasil belajar yang signifikan antara kelompok pebelajar yang menggunakan strategi pembelajaran jigsaw dengan kelompok pebelajar yeng menggunakan pembelajaran tradisional. 2) terdapat perbedaan hasil belajar antara kelompok yang memiliki keterampilan sosial tinggi dengan kelompok pebelajar yang memiliki keterampilan sosial rendah. 3) terdapat interaksi yang signifikan antara implementasi strategi pembelajaran kooperatif tipe (jigsaw dan tradisional) dengan tingkat keterampilan sosial (tinggi dan rendah) terhadap hasil belajar.
\end{abstract}

Kata kunci: strategi pembelajaran, jigsaw, tradisional, keterampilan sosial, dan hasil belajar.

\begin{abstract}
Jigsaw cooperative learning is considered better than individual learning, or competitive learning. The research is a quasi experiment using factorial nonequivalent control group design, applied with 4 parallel classes at the fifth grade in two elementary schools. The ANOVA factorial $2 \times 2$ (Anova two lines) applying with SPSS 16 was used to analyze. The results could be stated that there were significant achievements of jigsaw cooperative learning group with traditional group of students, the insignificant achievement between high social skill group of learners and low social skill group, and there was significant interaction between implementation of jigsaw cooperative learning strategy and traditional with social skill level.
\end{abstract}

Keywords: learning strategies, jigsaw, traditional, social skills, and learning outcomes. 


\section{PENDAHULUAN}

Bergesernya fokus pembelajaran dari paradigma behavioristik keparadigma konstruktivistik (Degeng, 2001) membawa perubahan besar terhadap konsep belajar dan pembelajaran. Pada paradigma behavioristik pembelajar hanya memberikan/menuangkan pengetahuan kepada pebelajar. Kondisi ini membawa pada ranah pembelajaran yang cenderung otoriter, dan mengabaikan perbedaan karakteristik pada individu. Sehingga banyak menimbulkan konflik dan gejolak sosial, baik di lingkungan sekolah atau di lingkungan sosial dalam skala luas (Aronson, et.al, 2009). Pelajaran teacher centered dapat menciptakan sasaran behavioral (perilaku), menganalisa tugas, dan menyusun taksonomi (klasifikasi) instruksional. Menciptakan sasaran behavioral (behavioral objectives) ialah pernyataan tentang perubahan yang diharapkan oleh pembelajar akan terjadi dalam kinerja pebelajar.

Materi Ilmu Pengetahuan Sosial (IPS) SD terdiri dari perpaduan empat ilmu sosial, seperti pendidikan sejarah, geografi, ekonomi, dan sosiologi. Keterpaduan tersebut dimaksudkan untuk membiasakan anak sejak usia SD dalam memecahkan masalah sosial dengan pendekatan secara utuh, tidak terkotak-kotak dari berbagai disiplin ilmu sosial. Misalnya, untuk memecahkan masalah gempa bumi tidak cukup didekati dengan pendekatan geografi saja, yang terkait dengan cuaca dan tekstur bumi, melainkan dilihat dari sejarahnya. Mengapa gempa sering terjadi, pada hal sebelumnya tidak sehebat tahun ini. Analisis dilandaskan pada pendekatan pendidikan masyarakat maupun kondisi sosial mereka. Anak SD perlu didasarkan supaya berpikir bahwa pemecahan masalah yang didasarkan berbagai disiplin ilmu akan menghasilkan yang lebih baik dan cepat teratasi (Depdiknas, 2006).
Selama ini yang dihadapi pada pelajaran IPS adalah adanya permasalahan lemahnya proses pembelajaran yang berdampak pada perolehan hasil belajar yang sangat rendah pada pebelajar. Proses pembelajaran kurang didukung dengan pengembangan kemampuan berpikir yang tinggi. Di dalam kelas pebelajar hanya diarahkan kepada kemampuan untuk menghafal informasi, anak dipaksa untuk mengingat berbagai informasi tanpa dituntut untuk memahami informasi yang dapat diingat dan dihubungkan dengan kehidupan sehari-harinya. Akibat dari itu pebelajar yang akan lulus dari sekolah, dan hidup di tengah-tengah masyarakat akan mengalami kepincangan dalam hal kehidupan sosial. Mereka sebenarnya pintar secara teori atau keilmuan tapi mereka miskin dalam bidang aplikasi dalam kehidupan sosial di masyarakat.

Secara empiris ada beberapa sekolah di tempat praktik pembelajaran IPS dilaksanakan masih banyak menjadikan metode ceramah sebagai andalannya, pembelajar/guru atau calon guru masih menjadi sumber belajar utama sedangkan pebelajar hanya berperan sebagai penerima informasi. Pebelajar juga tidak diberi kesempatan untuk belajar dari teman sebayanya melalui aktivitas kelompok untuk mengasah berbagai keterampilan pribadi sosial. Hal ini sejalan dengan pendapat Soemantri (2001) bahwa dalam pembelajaran IPS, masih banyak pembelajar yang menggunakan metode ekspositori untuk menyampaikan pelajaran IPS. Metode ceramah yang tidak menarik membuat pebelajar menjadi pasif, hanya sebagai penerima pengetahuan, tidak merangsang daya pikir dan keterampilan hidup lainnya.

Di samping kualitas pembelajaran IPS yang masih rendah saat ini pada dasarnya dapat disebabkan oleh beberapa faktor, diantaranya pengetahuan dan kemampuan pembelajar dalam memilih dan menerapkan 
berbagai strategi pembelajaran, terbatasnya media akibat kurang berinovasi, keberagaman kondisi pebelajar, rendahnya dukungan iklim sekolah terhadap optimalisasi daya kreativitas pembelajar, dan tuntutan yang terlalu besar porsinya pada penguasaan materi pelajaran. Tuntutan tingginya nilai kelulusan akhir aspek kognitif pebelajar memaksa pembelajar untuk lebih mengutamakan penguasaan keterampilan intelektual. Hal ini menyebabkan keberhasilan yang dicapai oleh pendidikan IPS baru pada tataran tingginya nilai akademik sedangkan orientasi pada aspek pengembangan keterampilan sosial masih terabaikan (Depdiknas, 2006)

Social skill merupakan keterampilan sosial dengan dimensi-dimensi yang melekat, yaitu keterampilan meneliti, keterampilan berfikir, keterampilan berpartisipasi sosial dan keterampilan berkomunikasi (Sapriya, 2011). Menurut Bandura (1977) dalam Gredler menguatkan, ... dalam konsep psikhologi, manusia digambarkan sebagai hasil interaksi timbal balik yang terusmenerus yang terjadi antara faktor-faktor penentu pribadi dan lingkungannya (Gredler, 1991; 369). Kompetensi social skill merupakan sebuah kompetensi dampak dari proses interaksi secara terus-menerus antara pebelajar, pembelajar, dan lingkungannya. Kompetensi penyerta secara alamiah harusnya melekat dalam kepribadian pembelajar, berarti kompetensi tersebut diperlukan oleh pembelajar di semua disiplin ilmu. Keterampilan sosial yang merupakan komponen kunci dari kecerdasan sosial meliputi; (1) kemampuan untuk mengekspresikan diri dalam interaksi sosial, (2) kemampuan untuk "membaca" dan memahami situasi sosial yang berbeda, (3) pengetahuan tentang peran sosial, norma, (4) interpersonal pemecahan masalah keterampilan, dan (5) sosial bermain peran keterampilan (Riggio \& Reichard, 2008)
Untuk mengatasi masalah pembelajaran tersebut, maka pembelajaran kooperatif (cooperative learning) jigsaw akan lebih efektif. Strategi pembelajaran yang dikatakan efektif, karena memungkinkan pebelajar saling membantu dan mendukung dan kerjasama saling tergantung (interdependence) untuk menyelesaikan tugas dalam proses belajar. Selain strategi dapat meningkatkan keterampilan sosial pebelajar dalam berkolaborasi untuk menyelesaikan tugas kelompok, misalnya dalam kelompok mereka membagi peran sesuai macam tugas seperti peran pencatat, pembuat kesimpulan, pengatur materi, atau fasilitator.

Falsafah yang mendasari pembelajaran kooperatif tipe jigsaw dalam pendidikan adalah "homo homoni socius" (pembelajaran gotong-royong) yang menekankan pada manusia sebagai mahluk sosial. Pembelajaran kooperatif terutama tipe jigsaw dianggap sangat cocok diterapkan di Indonesia karena sesuai dengan budaya Indonesia yang menjunjung tinggi nilai gotong royong. Strategi jigsaw adalah suatu teknik pembelajaran strategi kooperatif yang memiliki kesamaan dengan "pertukaran antar kelompok" tetapi menuntut tanggung jawab besar dari pebelajar dalam pembelajaran.

Eksperimen dalam penelitian digunakan kooperatif tipe jigsaw dan tradisional sebagai variabel bebas, Slavin (1995) menyatakan, salah satu strategi pembelajaran yang mendapat respon pada saat ini adalah strategi pembelajaran kooperatif. Pada pembelajaran pebelajar diberi kesempatan untuk berkomunikasi dan berinteraksi sosial dengan temannya untuk mencapai tujuan pembelajaran. Sementara pembelajar bertindak sebagai motivator dan fasilitator dalam aktivitas pebelajar. Artinya dalam pembelajaran ini kegiatan aktif dengan pengetahuan dibangun sendiri oleh pebelajar dan mereka bertanggung jawab atas hasil pembelajarannya. Lebih lanjut Arends (2007) 
mendeskripsikan tiga model pengajaran antara lain, pengajaran presentasi, pengajaran langsung, dan pengajaran konsep, dan modelmodel ini dapat digunakan untuk membantu pebelajar mendapatkan informasi baru, yang secara esensial disebut academic learning. Tipe pembelajaran penting tidak mempresentasikan tujuan satu-satunya bagi pebelajar. Arends (2007) mengungkapkan, pembelajaran kooperatif secara umum dibagi tiga struktur yang perlu diperhatikan dalam pembelajaran, yaitu (1) task structure (struktur tugas), melibatkan cara pembelajaran yang diorganisasikan dan jenis pekerjaan yang diperintahkan kepada pebelajar, (2) goal structure (tujuan struktur) sebuah pelajaran mengacu pada banyak interdepedensi yang dibutuhkan dari pebelajar ketika mereka melaksanakan tugasnya, dan (3) reward structure, dapat dicapai tanpa ketergantungan apa yang dilakukan orang lain. Selanjutnya Arends (2007) menegaskan tiga tujuan penting yang dapat dikembangkan dalam pembelajaran kooperatif, yaitu hasil belajar, toleransi, penerimaan terhadap keanekaragaman dan pengembangan keterampilan sosial.

Berdasarkan pernyataan diatas bahwa model pembelajaran perlu diperhatikan, karena dapat mempengaruhi hasil belajar. Berdasarkan temuan Suhirman (2008) hasil belajar juga dipengaruhi oleh beberapa faktor, diantaranya model pembelajaran, proses pembelajaran, tujuan dan karakteristik mata pelajaran. Dalam hal ini strategi pembelajaran kooperatif dapat memusatkan kegiatan belajar pada pebelajar dan memandang strategi sebagai subjek dan objek dalam belajar, serta mempunyai kemampuan dasar untuk berkembang secara optimal sesuai dengan potensi yang dimiliki. Dengan model ini pebelajar mengembangkan kreativitas dalam memahami masalah yang diarahkan pada pencapaian tujuan pembelajaran. Tingkat keterampilan sosial memberikan pengaruh terhadap pencapaian perolehan belajar pebelajar baik yang memiliki keterampilan sosial tinggi maupun keterampilan sosial rendah. Pembelajaran kooperatif dapat digunakan di Sekolah Dasar dan relevan untuk mata pelajaran Ilmu Pengetahuan Sosial (IPS).

Kenyataan di lapangan, peneliti melihat dalam kegiatan pembelajaran di Sekolah Dasar bersifat menoton, dan kurang kreatif untuk memberikan variasi dalam model pembelajaran. Sagala (2007) menyatakan bahwa dalam kegiatan proses pembelajaran lebih banyak pebelajar mendengarkan dengan teliti mencatat pokok penting yang dikemukakan oleh pembelajar. Kegiatan pembelajaran ini kurang memberikan kesempatan kepada pebelajar untuk berdiskusi dan kurang memotivasi pebelajar belajar, dan kurang memberikan kesempatan untuk mengemukakan pendapat kepada pebelajar sebagai keterampilan sosial untuk bertanya. Pembelajaran belum menunjukkan kooperatif dan masih mengerjakan tugas di kelas sehingga kegiatan pembelajaran berpusat pada guru (teachers centered) lebih banyak pemberian tugas di kelas tanpa didampingi pembelajar. Pembelajar dalam melaksanakan kegiatan pembelajaran masih mendominasi kelas, interaksi antara pembelajar dan pebelajar kurang, serta komunikasi yang terjadi masih satu arah. Hal ini dapat dikatakan bahwa pembelajaran yang digunakan belum bersifat kerjasama.

Arends (2008) bahwa keterampilan sosial adalah perilaku-perilaku yang mendukung kesuksesan hubungan sosial dan meningkatkan individu untuk bekerjasama dengan orang lain secara efektif. Keterampilan sosial sangat dibutuhkan untuk hidup dan bekerjasama dibidang keterampilan berpartisipasi, dan keterampilan berkomunikasi. Dalam hal ini pembelajar dapat membantu pebelajar menguasai keterampilan-keterampilan antara lain keterampilan berbagi, yaitu membantu 
teman yang mengalami kesulitan untuk membagi waktu dan bahan-bahan yang akan dibagi untuk persiapan tugas-tugas pembelajaran.

Menyikapi permasalahan yang berkaitan dengan kondisi kegiatan pembelajaran di kelas, rendahnya hasil belajar pebelajar dalam mengerjakan pekerjaan rumah IPS dan inovasi dalam proses pembelajaran. Untuk meningkatkan hasil belajar, pembelajar perlu menerapkan strategi pembelajaran yang berpusat pada pebelajar, supaya dapat mengaktifkan pebelajar dan memberi kesempatan kepada pebelajar untuk mengkonstruk pengetahuan, dan memberi peluang untuk bekerjasama dalam menggali ilmu pengetahuan dan memecahkan suatu masalah. Strategi pembelajaran yang dapat mengaktifkan pebelajar untuk dapat meningkatkan hasil belajar adalah strategi pembelajaran kooperatif tipe jigsaw.

Jhonson and Jhonson (dalam Sobari, 2006: 31) melakukan penelitian yang hasilnya menunjukkan bahwa interaksi kooperatif memiliki berbagai pengaruh positif terhadap perkembangan anak. Pengaruh positif adalah; (1) meningkatkan hasil belajar, (2) meningkatkan daya ingat, (3) dapat digunakan untuk mencapai taraf penalaran tingkat tinggi, (4) mendorong tumbuhnya motivasi instrinsik,

meningkatkan hubungan antar manusia yang heterogen, (6) meningkatkan sikap anak yang positif terhadap sekolah, (7) meningkatkan sikap positif terhadap pembelajar, (8) meningkatkan harga diri anak, meningkatkan perilaku penyesuaian sosial yang positif, (10) meningkatkan keterampilan hidup bergotong royong.

$\begin{array}{ccc}\begin{array}{c}\text { Dengan } \\ \text { pembelajaran }\end{array} & \begin{array}{c}\text { demikian } \\ \text { kooperatif }\end{array} & \text { dalam } \\ \text { jigsaw, }\end{array}$ memungkinkan interaksi antar pebelajar, sehingga pebelajar dengan hiterogenitas, kemampuannya saling terlibat. Karena kooperatif sangat erat dengan interaksi sosial (social skill). dengan interaksi sosial dalam kelompok maka kelemahan salah satu anggota kelompok akan dapat dibantu oleh kemampuan anggota kelompok yang lain (Sharan \& Sharan, 1992, 1994)

Pelajaran Ilmu Pengetahuan Sosial (IPS) di SD harus memperhatikan kebutuhan anak yang berusia antara 6-12 tahun. Anak yang masuk kelompok usia 7-11 tahun menurut Piaget (1963) berada dalam perkembangan kemampuan intelektual/kognitifnya pada tingkatan konkrit operasional. Materi IPS penuh dengan pesan-pesan yang bersifat abstrak. Konsep-konsep seperti waktu, perubahan, kesinambungan (continuity), arah mata angin, lingkungan, ritual, akulturasi, kekuasaan, demokrasi, nilai, peranan, permintaan, atau kelangkaan adalah konsepkonsep abstrak yang dalam program mata pelajaran Ilmu Pengetahuan Sosial (IPS) harus dibelajarkan kepada pebelajar SD.

Pendidikan Ilmu Pengetahuan Sosial (IPS) SD disajikan dalam bentuk synthetic science, karena basis dari disiplin terletak pada fenomena yang telah diobservasi di dunia nyata. Konsep, generalisasi, dan temuan-temuan penelitian dari synthetic science ditentukan setelah fakta terjadi atau diobservasi, dan tidak sebelumnya, walaupun diungkapkan secara filosofis. Para peneliti menggunakan logika, analisis, dan keterampilan (skills) lainnya untuk melakukan inkuiri terhadap fenomena secara sistematik. Agar diterima, hasil temuan dan prosedur inkuiri harus diakui secara publik (Welton and Mallan, 1988:66-67)

Sesuai dengan karakteristik anak dan Ilmu Pengetahuaan Sosial (IPS) SD, maka metode ekspositori akan menyebabkan pebelajar bersikap pasif, dan menurunkan derajat Ilmu Pengetahuan Sosial (IPS) menjadi pelajaran hafalan yang membosankan. Pembelajar yang bersikap memonopoli peran sebagai sumber informasi, selayaknya meningkatkan 
kinerjanya dengan metode pembelajaran yang bervariasi, seperti menyajikan cooperative learning model; role playing, jigsaw, membaca sajak, buku (novel), atau surat $\mathrm{kabar} / \mathrm{majalah} / \mathrm{jurnal}$ agar pebelajar diikutsertakan dalam aktivitas akademik

Pembelajaran kooperatif merupakan proses pembelajaran yang lebih menekankan kepada proses kerjasama dalam kelompok. Tujuan yang ingin dicapai tidak hanya kemampuan akademik dalam pengertian penguasaan bahan pelajaran, tetapi adanya unsur kerjasama untuk penguasaan materi tersebut. Adanya kerjasama inilah yang menjadi ciri khas dari pembelajaran kooperatif.

Pembelajaran model jigsaw dikenal juga dengan kooperatif para ahli. Karena anggota setiap kelompok dihadapkan pada permasalahan yang berbeda. Tetapi permasalahan yang dihadapi setiap kelompok yang sama, setiap utusan dalam kelompok yang berbeda membahas materi yang sama, kita sebut sebagai tim ahli yang bertugas membahas permasalahan yang dihadapi, selanjutnya hasil pembahasan dibawa ke kelompok asal disampaikan pada anggota kelompoknya.

Pada strategi pembelajaran kooperatif jigsaw, terdapat kelompok asal dan kelompok ahli. Kelompok asal, yaitu kelompok induk pebelajar yang beranggotakan pebelajar dengan kemampuan asal, dan latar belakang keluarga yang beragam. Kelompok asal merupakan gabungan dari beberapa ahli. Kelompok ahli, yaitu kelompok pebelajar yang terdiri dari anggota kelompok asal yang berbeda yang ditugaskan untuk mempelajari dan mendalami topik tertentu dan menyelesaikan tugas-tugas yang berhubungan dengan topiknya untuk kemudian dijelaskan kepada anggota kelompok asal. Hubungan antar kelompok asal dan kelompok ahli (Arends, 2007).

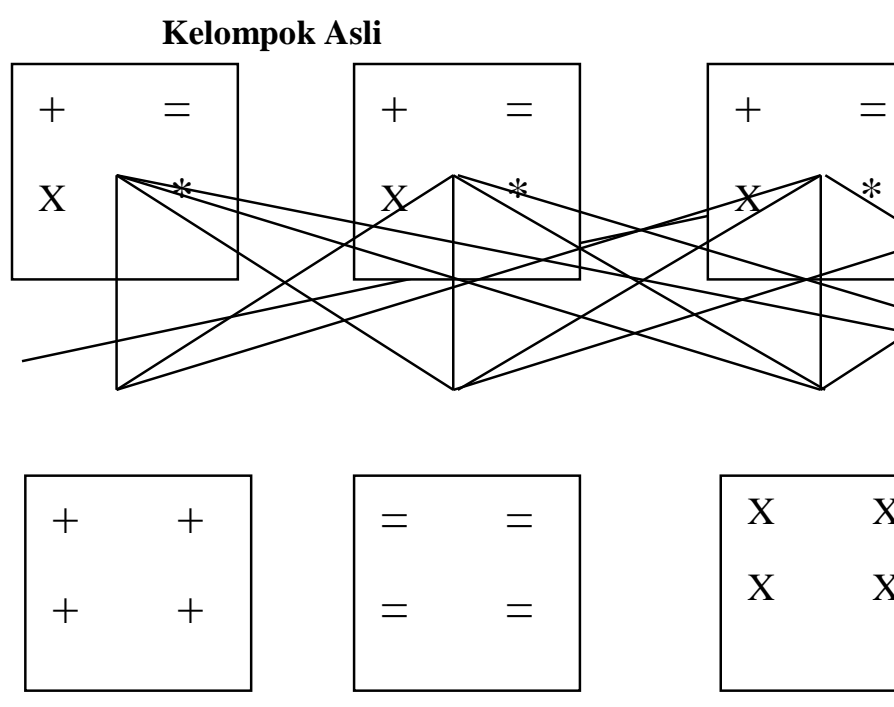

Kelompok Ahli

(Sumber: Arends, 2007)

Gambar 1 Kerangka Pembelajaran kooperatif jigsaw

\section{Keterangan:}

$\mathrm{A}=$ Posisi kelompok asli (induk); siswa secara bersama dalam kelompok mendapatkan secara bersama-sama.

$\mathrm{B}=$ Posisi kelompok ahli (khusus); siswa bergabung dalam kelompok-kelompok ahli, model pembelajaran kooperatif jigsaw dapat dijelaskan dalam bagan sebagai berikut (Slavin, 1995)

Tabel 1 Sintaks Pembelajaran Kooperatif Jigsaw NO TAHAP URAIAN KEGIATAN

1. Tahap
Pendahuluan $\begin{gathered}\text { 1.Guru memberikan review, apersepsi, } \\ \text { motivasi kepada seluruh siswa }\end{gathered}$

2.Menjelaskan kepada siswa tentang model pembelajaran yang dipakai dan menjelaskan bahwa setiap siswa dituntut bertanggung jawab pada bagian materi yang dipelajari.

3.Pembentukan kelompok

4.Setiap kelompok terdiri dari 4-6 siswa dengan kemampuan siswa yang heterogen

5.Pembagian materi/soal pada masingmasing anggota kelompok.

2. Tahap Penguasaan

1.Siswa mempelajari materi/soal yang menjadi bagiannya, selanjutnya bergabung dalam kelompok ahli dan berusaha menguasai materi sesuai 


\begin{tabular}{ll}
\hline & $\begin{array}{l}\text { dengan soal yang diterima, dengan } \\
\text { soal/materi sama. }\end{array}$ \\
& $\begin{array}{l}\text { 2.Guru memberikan bantuan } \\
\text { sepenuhnya kepada siswa untuk } \\
\text { menguasai materi pelajaran. }\end{array}$ \\
\hline 3. Tahap & 1.Setiap siswa kembali ke kelompok \\
Penularan & $\begin{array}{l}\text { 2.Setelah selesai diskusi sebagai team } \\
\text { ahli tiap anggota kembali ke } \\
\text { kelompok asal dan bergantian } \\
\text { mengajar teman satu team mereka } \\
\text { tentang sub bab yang mereka kuasai } \\
\text { dan tiap anggota lainnya } \\
\text { mendengarkan dengan sungguh- } \\
\text { sungguh. } \\
\text { 3.Diharapkan terjadi diskusi antar } \\
\text { siswa dalam kelompok asal. } \\
\text { 4.Dari hasil saling memberikan } \\
\text { penjelasan atau diskusi dalam } \\
\text { kelompok diharapkan siswa mampu } \\
\text { mengerjakan atau menjawab soal } \\
\text { yang diberikan oleh guru. }\end{array}$ \\
\hline 1.Guru bersama siswa membahas soal \\
yang telah dikerjakan. \\
2.Kuis/evaluasi dan penskoran hasil \\
jawaban siswa.
\end{tabular}

(Sumber; Arends, 2007)

Tuckman, (1999) menyatakan pembelajaran tradisional sebagai model transisi yang mengasumsikan bahwa pengetahuan terdiri dari fakta-fakta diskrit yang harus dipelajari oleh pebelajar. Pebelajar memperoleh informasi dengan cepat dan seksama melalui aktivitas mendengarkan, membaca informasi yang diterima, menjawab pertanyaan-pertanyaan yang berkaitan secara cepat dan tepat.

Untuk merefleksi materi yang dipresentasikan, menghubungkan dengan pengetahuan sebelumnya, mengaplikasikan kepada situasi kehidupan yang nyata. Lebih lanjut dinyatakan bahwa pembelajaran tradisional memiliki ciri-ciri yaitu; (1) pembelajaran berpusat pada pembelajar, (2) pembelajaran pasif, (3) di antara pebelajar kurang berinteraksi, (4) tidak ada kelompokkelompok kooperatif, dan (5) penilaian bersifat sporadis. Menurut Brooks dan
Brooks (1993), penyelenggaraan pembelajaran tradisional lebih menekankan kepada tujuan pembelajaran berupa penambahan pengetahuan, sehingga belajar dilihat sebagai proses meniru dan pebelajar dituntut untuk dapat mengungkapkan kembali pengetahuan yang sudah dipelajari melalui kuis atau test yang terstandar.

Sumber belajar dalam pendekatan pembelajaran tradisional lebih banyak berupa informasi verbal yang diperoleh dari buku dan penjelasan pembelajar atau ahli. Sumber belajar (informasi) harus tersusun secara sistematis mengikuti urutan dari komponen-komponen yang kecil keseluruhan (Oliver \& Hannafin, 2001) dan biasanya bersifat deduktif. Pebelajar yang telah mempelajari pengetahuan dasar tertentu, maka pebelajar diharapkan akan dapat menggabungkan sub-sub pengetahuan tersebut untuk menampilkan perilaku yang lebih kompleks.

Tabel 2 Sintaks Pembelajaran Tradisional

\begin{tabular}{|c|c|c|}
\hline No & Kegiatan guru & Kegiatan siswa \\
\hline 1. & $\begin{array}{l}\text { Menyampaikan } \\
\text { pokok bahasan yang } \\
\text { akan diberikan }\end{array}$ & $\begin{array}{l}\text { Mendengarkan } \\
\text { informasi } \\
\text { pendidik }\end{array}$ \\
\hline 2. & $\begin{array}{l}\text { Menanyakan materi- } \\
\text { materi pendahuluan } \\
\text { yang terkait }\end{array}$ & $\begin{array}{l}\text { Merespon pertanyaan } \\
\text { pendidik }\end{array}$ \\
\hline 3. & 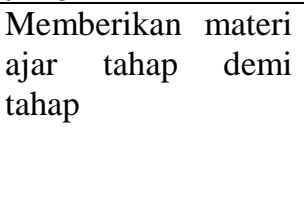 & $\begin{array}{l}\text { Memperhatikan } \\
\text { penjelasan guru dan } \\
\text { mencatat materi yang } \\
\text { dijelaskan oleh } \\
\text { pendidik }\end{array}$ \\
\hline 4. & $\begin{array}{l}\text { Memberikan contoh } \\
\text { soal }\end{array}$ & $\begin{array}{l}\text { Memperhatikan dan } \\
\text { mencatat contoh soal }\end{array}$ \\
\hline 5. & $\begin{array}{l}\text { Menugasakan } \\
\text { kepada siswa untuk } \\
\text { mengerjakan soal di } \\
\text { LKS }\end{array}$ & $\begin{array}{l}\text { Mengerjakan soal- } \\
\text { soal yang ada di LKS }\end{array}$ \\
\hline 6. & \begin{tabular}{l}
\multicolumn{3}{l}{ Menyimpulkan } \\
materi yang telah \\
diberikan \\
memberikan \\
pekerjaan rum \\
(PR)
\end{tabular} & $\begin{array}{lr}\text { Mencatat } & \text { kesimpulan } \\
\text { yang } & \text { diberikan } \\
\text { pendidik } & \text { dan } \\
\text { mencatat PR } & \end{array}$ \\
\hline
\end{tabular}

( Dikutip dari Johnson \& Johnson, 2007 ) 
Teori Bandura menjelaskan perilaku manusia dalam konteks interaksi timbal balik yang berkesinambungan antara kognitif, perilaku dan pengaruh lingkungan. Kondisi lingkungan sekitar individu sangat berpengaruh pada pola belajar sosial. Teori belajar juga dikembangkan untuk menjelaskan bagaimana seseorang belajar dalam keadaan atau lingkungan yang sebenarnya. Bandura (1977) menghipotesiskan bahwa tingkah laku ( $\mathrm{B}=$ behavior $)$, lingkungan $(\mathrm{E}=$ environment $)$ dan kejadian-kejadian internal pada pelajar yang mempengaruhi persepsi dan aksi $(\mathrm{P}=$ perception) adalah merupakan hubungan yang saling berpengaruh atau berkaitan (interlocking), menurut Albert Bandura, tingkah laku sering dievaluasi ialah bebas dari timbal balik sehingga boleh mengubah kesan-kesan personil seseorang, pengakuan sosial yang berbeda mempengaruhi konsepsi diri individu. Teori belajar sosial menekankan, bahwa lingkungan yang dihadapkan pada seseorang secara kebetulan, lingkungan kerap kali dipilih dan diubah oleh orang melalui perilakunya sendiri. Menurut Bandura, bahwa "sebagian besar manusia belajar melalui pengamatan secara selektif dan mengingat tingkah laku orang lain“. Inti dari teori pembelajaran sosial adalah pemodelan (modeling), dan pemodelan merupakan salah satu langkah paling penting dalam pembelajaran terpadu.

Pengertian yang dikemukakan oleh Sjamsuddin dan Maryani (2008; 6), keterampilan sosial adalah suatu kemampuan secara cakap yang tampak dalam tindakan, mampu mencari, memilih dan mengolah informasi, mampu mempelajari hal-hal baru untuk memecahkan masalah sehari-hari, memiliki keterampilan berkomunikasikan baik lisan maupun tulisan, memahami, menghargai, dan mampu bekerjasama dengan orang lain yang majemuk, mampu mentransformasikan kemampuan akademik dan beradaptasi dengan perkembangan masyarakat global.

Keterampilan sosial (social skill) adalah kemampuan individu untuk berkomunikasi efektif dengan orang lain baik secara verbal maupun non verbal sesuai dengan situasi dan kondisi yang ada pada saat itu, di mana keterampilan sosial akan mampu mengungkapkan perasaan baik positif maupun negatif dalam hubungan interpersonal, tanpa harus melukai orang lain (Hargie, Saunders \& Dickson dalam Merrell dan Gimpel, 1998). Dalam kelompok keterampilan sosial membawa orang untuk lebih berani berbicara, mengungkapkan setiap perasaan atau permasalahan yang dihadapi dan sekaligus menemukan penyelesaian yang adaptif, sehingga mereka tidak mencari pelarian ke hal-hal yang lain justru dapat merugikan diri sendiri maupun orang lain.

Berdasarkan pernyataan diatas, keterampilan sosial dapat membantu kelancaran dalam berkomunikasi, dalam mendukung interaksi kerjasama dalam hal mengemukakan pendapat, menerima saran, dan menengahi pendapat-pendapat yang belum dapat terselesaikan. Membantu pebelajar memahami lingkungan fisik, sehingga menjadi warga negara yang baik dalam masyarakat.

Seiring dengan berkembangnya keterampilan sosial pebelajar, maka keterampilan sosial telah berkembang secara intensif. Perspektif motivational pada pembelajaran kooperatif terutama memfokuskan pada penghargaan atau struktur tujuan (Slavin, 2008). Dalam pembelajaran kooperatif jigsaw pebelajar bekerjasama, selalu hadir di kelas dan membantu yang lainnya belajar akan dipuji dan didukung oleh teman satu timnya. (Slavin, 2008). Hal ini sesuai dengan peran dan kedudukan anggota anggota kelompok dalam tugasnya sebagai kelompok ahli yang menjadi wakil kelompok asli untuk mencari 
dan menyampaikan kembali bahan materi yang dikaji dalam jigsaw. Maka keterampilan sosial akan memberikan pengaruh pada hasil belajar pebelajar pada mata pelajaran Ilmu Pengetahuan Sosial (IPS) pada lembaga Sekolah Dasar.

Prestasi belajar (hasil belajar) merupakan gambaran penguasaan pebelajar yang diukur berdasarkan jumlah skor atau presentase jumlah skor jawaban benar atas soal yang disusun sesuai dengan tujuan pembelajaran yang telah ditetapkan. Gagne (1985) mengungkapkan bahwa keterampilan, apresiasi, dan penalaran manusia dengan semua variasinya, dan juga harapan, aspirasi, sikap, dan nilai-nilai manusia, umumnya diakui bahwa perkembangannya sebagian besar bergantung pada peristiwa yang disebut dengan belajar.

Hasil Belajar menurut Bloom (dalam Degeng, 1989), yaitu: 1) ranah kognitif yang berhubungan dengan kemampuan berfikir, 2) ranah afektif yang berhubungan dengan minat, perasaan, sikap, emosi, kepribadian penghargaan, proses internalisasi dan pembentukan karakteristik diri, dan 3) ranah psikhomotorik yang berhubungan dengan persoalan keterampilan motorik yang dikendalikan oleh kematangan psikhologis. Dalam taksonami Bloom ranah kognitif diklasifikasikan kedalam 6 (enam) jenjang, secara berturut dari jenjang kemampuan tinggi ke jenjang kemampuan rendah yakni: pengetahuan, pemahaman, penerapan, analisis, sintesa, dan evaluasi. Kemudian ranah afektif membagi dalam lima jenjang. Kelima jenjang tersebut adalah: penerimaan (receiving), penanggapan (responding) penghargaan (valuing), pengorganisasian (organization), dan penjatidirian (characterization). Selanjutnya ranah psikhomotorik membagi kedalam 6 (enam) jenjang yakni: gerakan refleks, gerakan badan yang mendasar, kemampuan persepsi, kemampuan fisik, keterampilan gerakan, dan komunikasi yang beraturan.
Reigeluth mengatakan bahwa belajar adalah usaha untuk mengubah tingkah laku yang meliputi penambahan ilmu pengetahuan, peningkatan kecakapan, keterampilan, sikap, pengertian, harga diri, minat, watak, penyesuaian diri (Reigeluth 1999; 52-55). Hal demikian dinyatakan juga oleh Sardiman bahwa belajar merupakan usaha mengubah kemampuan sehingga menjadi lebih baik dari keadaan sebelumnya. (Sardiman, 2004; 10) Pengertian dan penekanan yang agak berbeda diungkapkan oleh oleh Moore bahwa belajar adalah perubahan yang relatif permanen pada kapasitas kemampuan seseorang sebagai hasil dari pengalaman dan latihan (Moore, 2005; 451). Moore lebih menekankan pentingnya mengalami dan melakukan latihan untuk membentuk kemampuan. Mengalami dan berlatih merupakan kegiatan yang intensif dan terus menerus dilakukan, sehingga dengan aktivitas pengulangan tersebut menjadi pembentuk kemampuan yang diharapkan. Ini menandakan bahwa beberapa orang penulis di atas menempatkan pada aspek proses yang harus dilakukan oleh seseorang mengakibatkan seseorang itu memiliki kemampuan yang diharapkan.

$$
\text { Dalam proses pembelajaran }
$$

diperlukan perencanaan belajar sesuai dengan pandangan (Eggen, Kauchak, 2007; 407) mengungkapkan bahwa penekanan yang penting dalam tahap pertama yang paling esensial dilakukan oleh pembelajar perlu bertanya sebelum menentukan pebelajar belajar, apa topik yang semestinya pebelajar ketahui (Eggen, Kauchak, 2007; 407), dari hal ini terjembatani antara pemikiran dan pemahaman tentang belajar, perencanaan belajar, tujuan belajar dan hasil belajar yang diharapkan dari para pebelajar.

Pandangan Eggen selanjutnya adalah bahwa belajar harus memiliki tujuan yang dapat dikatakan sebagai hasil belajar atau learning goals maupun learning outcomes ataupun learning objektive dari kegiatan 
pembelajaran. Berarti hasil belajar merupakan produk atau hasil yang didapat setelah proses pembelajaran selesai dilakukan. Pandangan lain yang sesuai dengan itu, Uno menyatakan bahwa tujuan pembelajaran adalah pernyataan tentang hasil pembelajaran apa yang diharapkan. Tujuan ini masih bersifat umum, sangat khusus atau dimana dalam kontinu khusus (Uno, 2008; 20). Sedangkan Gagne dalam Uno menyatakan bahwa hasil belajar nampak dari kemampuan yang diperoleh pebelajar, dapat dilihat dari 5 (lima) katagori yaitu keterampilan intelektual, informasi verbal, strategi kognitif, keterampilan motorik dan sikap. Hal ini sejalan dengan pandangan Bloom yang mengatakan bahwa hasil belajar meliputi tiga aspek yakni kognitif, afektif dan psikhomotor (dalam Uno, 2008; 88)

Pada tingkat kegiatan belajar lebih menekankan kemampuan kognitif dan berpikir serta pembentukan kemampuankemampuan fisik dan mental. Sedangkan keberhasilan usaha belajar diukur berdasarkan standar-standar tertentu, yang menentukan tercapai tidaknya tujuan pembelajaran. Penilaian hasil belajar adalah proses pemberian nilai terhadap hasil-hasil belajar yang dicapai pebelajar dengan kriteria tertentu (Anderson, 2001; 27-30). (Slavin, 2000; 192). Winataputra (1993; 12) mengungkapkan bahwa hasil belajar adalah segala sesuatu yang menjadi milik pebelajar sebagai akibat dari yang dilakukan. Dengan demikian hasil belajar tampak apabila terjadinya perubahan tingkah laku pada diri pebelajar, yang dapat diamati dan diukur dalam bentuk perubahan pengetahuan, sikap dan keterampilan.

Jika hasil belajar disini adalah kemampuann penguasaan pengetahuan berupa fakta, konsep generalisasi maupun teori yang ada dalam bidang studi yang diajarkan, sikap yang terbentuk maupun keterampilan yang dapat ditunjukkan oleh pebelajar. Hasil belajar dapat diukur oleh peneliti bekerjasama dengan pembelajar bidang studi berdasarkan kisi-kisi yang disusun bersama berpedoman pada kurikulum yang telah diberlakukan dalam bidang studi Ilmu Pengetahuan Sosial (IPS).

\section{METODE}

Rancangan penelitian yang digunakan adalah rancangan eksperimen semu (quasi experiment). Penelitian ini menggunakan kuasi eksperimen karena dalam penelitian ini tidak memungkinkan untuk mengontrol semua variabel yang relevan, kecuali beberapa dari variabelvariabel tersebut (Suryabrata, 2003). Hal ini akan melakukan kontrol terhadap seluruh variabel yang dapat berpengaruh terhadap hasil belajar. Variabel penelitian terdiri dari variabel bebas, moderator, dan terikat. Variabel bebas berupa strategi pembelajaran kooperatif jigsaw dan pembelajaran tradisional. Variabel moderator berupa keterampilan sosial yang memiliki tingkatan tinggi dan rendah. Sedangkan variabel terikatnya adalah hasil belajar Ilmu Pengetahuan Sosial (IPS) pada lembaga Sekolah Dasar.

Lokasi penelitian dilakukan di Sekolah Dasar Kabupaten Bangkalan pada SDN Kemayoran 01 dan SDN Demangan 01 kedua sekolah tersebut memiliki karakteristik yang sama, baik pada sarana dan prasarana, pebelajar maupun kualifikasi pembelajar pengajarnya. Penerapan pembelajaran kooperatif jigsaw dilakukan pada kelas eksperimen di berlakukan pada 2 (dua) kelas masing-masing sekolah, dan kelas kontrol juga 2 (dua) kelas. Sehingga dalam penelitian digunakan 4 (empat) kelas secara keseluruhan baik kontrol maupun perlakuan (treatment)

Rancangan kuasi eksperimen the nonequivalent control group design adalah salah satu eksperimen yang biasa digunakan, terutama ketika tidak memungkinkan atau sulit menetapkan subjek secara random untuk 
pengelompokan (randomly to group). Peneliti menggunakan kelompok utuh (intact group), sehingga situasi ini dengan serta merta menurunkan kekuatan rancangan untuk menetapkan hubungan kausal.

Berdasarkan desain eksperimen nonequivalent control group design, maka eksperimen faktorial 2 x 2 yang digunakan mengikuti pola rancangan faktorial tersebut ini dan dapat ditentukan pengaruh utama (main effect) dan pengaruh interaksi (interaction effect) dari semua variabel perlakuan.

Keempat kelas diberikan pretest yang terdiri atas 50 butir soal tentang materi pelajaran Ilmu Pengetahuan Sosial (IPS). Soal test berbentuk pilihan ganda. Pemberian test dilaksanakan pada awal kegiatan penelitian. Bentuk dan soal test yang diberikan kepada pebelajar, baik itu kelas pembelajaran jigsaw dan tradisional adalah sama. Maksud pemberian test ini adalah untuk menentukan bahwa keempat kelas memiliki kemampuan yang setara. Uji analisis yang digunakan adalah uji $t$ dan semua perhitungan menggunakan bantuan komputer dengan program

SPSS.

Jumlah peserta pretest pada kelompok pembelajaran jigsaw adalah 60 orang dengan rerata 40,70 dan standar deviasi 3,500 sedangkan peserta pretest pada kelompok pembelajaran tradisional adalah 60 orang rerata 35,97 dan standar deviasi 3,813 Berarti kedua kelompok yang dijadikan penelitian memiliki rerata yang tidak berbeda jauh.

Variabel-variabel eksperimen dalam penelitian berupa; (1) variabel bebas (variabel independent) adalah strategi pembelajaran kooperatif dengan dimensi strategi pembelajaran kooperatif jigsaw dan strategi pembelajaran non-kooperatif tradisional, (2) variabel moderator adalah keterampilan sosial yang terdiri dari keterampilan sosial yang tinggi dan keterampilan sosial yang rendah, dan (3) variabel terikat (dependent variable) variabel yang akan diteliti adalah hasil belajar. Hasil belajar adalah skor yang diperoleh pebelajar dari hasil paska test.

Instrumen penelitian adalah alat atau sarana yang digunakan untuk memperoleh atau mengumpulkan data yang dibutuhkan dalam rangka memecahkan masalah yang hendak diteliti atau mencapai tujuan penelitian, baik berupa test, angket atau peralatan lainnya. Instrumen yang digunakan dalam penelitian ini dikelompokkan menjadi dua jenis, yaitu (1) instrumen untuk mengukur keterampilan sosial dan instrumen untuk mengukur hasil belajar. (1) instrumen untuk mengukur keterampilan sosial.

Untuk memperoleh data tentang tingkat keterampilan sosial, peneliti membuat angket dengan tetap berpedoman pada instrumen keterampilan sosial yang telah disusun oleh Robinson (dalam Cohen, 1994:4) yang diadaptasi oleh Degeng (1991). Instrumen keterampilan sosial yang digunakan dengan angket (kuesioner). Variabel penelitian diukur dengan menggunakan skala likert. Faktor-faktor keterampilan sosial yang diukur adalah 1) bercakap-cakap, 2) membuka diri, 3) mengungkapkan perasaan, 4) merasakan perasaan orang lain. berdasarkan beberapa faktor yang jumlah instrumennya sebanyak 16 butir pernyataan teruji, yang dikelompokkan ke dalam 4 (empat) faktor, yakni faktor 1) keterampilan komunikasi/bercakap-cakap, 2) keterampilan bertanya/membuka diri, 3) keterampilan menjawab/mengungkapkan perasaan, 4) keterampilan berbagi/merasakan perasaan orang lain. Test keterampilan sosial ini berupa pernyataan, jawaban setiap pernyataan menggunakan skala likert (skala 1-4), skala likert dimodifikasi oleh peneliti dengan membagi ke dalam 4 titik pilihan dengan interval diasumsikan berjarak sama. Untuk pernyataan positif, pilihan jawaban tidak pernah pada titik 1 , jarang pada titik 2 , 
sering pada titik 3, selalu pada titik 4. Dan sebaliknya untuk pernyataan negatif, pilihan jawaban tidak pernah pada titik 4, jarang pada titik 3, sering pada titik 2, selalu pada titik 1 (Suhirman, 2008)

(2) instrumen untuk mengukur hasil belajar Instrumen untuk mengukur hasil belajar merupakan instrumen untuk mengukur variabel dependen sebagai akibat langsung perlakuan. Instrumen test hasil belajar berupa pretest dan post-test. Instrumen yang digunakan untuk mengukur pretest adalah test pilihan ganda. Test pilihan ganda terdiri dari 50 soal dengan memilih alternatif jawaban, jika benar nilai masingmasing soal adalah satu dan jika salah nilainya nol, sehingg nilai maksimal ideal test adalah 50 .

Test ini diberikan sebelum perlakuan (pretest) dan setelah perlakuan (post-test). Dengan demikian, pretest dan post-test menggunakan test yang sama. Hasil yang diperoleh melalui pretest dan post-test akan digunakan sebagai unit analisis penelitian data dalam statistik.

Test objektif adalah test yang dalam pemeriksaannya dapat dilakukan secara objektif. Hal ini dimaksudkan untuk mengatasi kelemahan-kelemahan dari test bentuk essei (Arikunto, 2003:164)

Test objektif menuntut pebelajar untuk memilih jawaban yang benar diantara kemungkinan jawaban yang telah disediakan, memberikan jawaban singkat, dan melengkapi pertanyaan atau pernyataan yang belum sempurna. Test objektif sangat cocok untuk menilai kemampuan pebelajar yang menuntut proses mental yang tidak begitu tinggi seperti kemampuan mengingat kembali, kemampuan mengenal kembali, pengertian, dan kemampuan mengaplikasikan prinsip-prinsip.

\section{HASIL \& PEMBAHASAN}

Dalam bagian ini akan dipaparkan mengenai deskripsi umum hasil penelitian yang dipaparkan pada bagian ini meliputi: 1) deskripsi hasil test hasil belajar pada kelompok strategi pembelajaran kooperatif (jigsaw dan tradisional), 2) deskripsi hasil angket keterampilan sosial yang diberikan pada pebelajar. Didasarkan pada hasil analisis deskripsi sampel penelitian yang berjumlah 120 pebelajar. Berikut ini dipaparkan keadaan sampel penelitian berdasarkan keterampilan sosial dan strategi pembelajaran.

Strategi pembelajaran tradisional rerata skor post-test pebelajar yang memiliki keterampilan sosial tinggi $(\mathrm{M}=39,30 ; \mathrm{SD}=$ 3,302) lebih besar dari pada rerata skor posttest pebelajar yang memiliki keterampilan sosial rendah $(\mathrm{M}=35,30 ; \mathrm{SD}=3,576)$. Rerata skor post-test pebelajar yang memiliki keterampilan sosial tinggi dalam strategi pembelajaran jigsaw $(\mathrm{M}=40,79 ; \mathrm{SD}=$ 3,543 ) lebih besar dari pada rerata skor posttest pebelajar yang memiliki keterampilan sosial rendah $(\mathrm{M}=40,47 ; \mathrm{SD}=3,484)$. Berdasarkan jumlah total diketahui bahwa rerata skor post-test pebelajar pada penerapan strategi pembelajaran jigsaw $(\mathrm{M}=40,70$; $\mathrm{SD}$ $=3,500$ ) lebih besar dari pada rerata skor post-test pada penerapan strategi pembelajaran tradisional $(\mathrm{M}=35,97 ; \mathrm{SD}=$ 3,813 )

Dalam bagian ini dipaparkan tentang hasil pengujian asumsi dan hipotesis penelitian. Pengujian asumsi keparametrikan menyangkut uji normalitas dan uji homogenitas data. Pengujian hipotesis penelitian menyangkut pengujian pengaruh utama dan pengaruh interaksi antar variabel penelitian. Pemaparan didahului dengan kegiatan pengujian asumsi dan dilanjutkan dengan kegiatan pengujian hipotesis penelitian. 
Terdapat dua hal yang dilakukan dalam pengujian asumsi, yaitu uji normalitas dan uji homogenitas data. Dalam penelitian ini uji normalitas menggunakan uji statistik Kolmogorov-Smirnov dan Shapiro-Wilk. Uji homogenitas (Test of Homogenety of Variances) dengan Levene Statistic digunakan untuk menguji apakah varian antar kelompok tersebut sama (Pratisto, 2004)

Pengujian asumsi yang pertama adalah uji normalitas. Uji normalitas dilakukan untuk mengetahui kenormalan distribusi data. Uji normalitas data menggunakan uji statistik KolmogorovSmirnov. Berikut ini disajikan hasil uji normalitas dari data post-test pebelajar, baik yang diajar dengan strategi pembelajaran jigsaw maupun yang diajar dengan strategi pembelajaran tradisional.

Tabel 3 Hasil Uji Normalitas Data Post-test One-Sampel Kolmogorov-Smirnov Test

\begin{tabular}{|c|c|c|}
\hline & & $\begin{array}{l}\text { HASIL } \\
\text { BELAJAR }\end{array}$ \\
\hline $\mathrm{N}$ & & 120 \\
\hline $\begin{array}{l}\text { Normal } \\
\text { Parameters a.b }\end{array}$ & Mean & 38,33 \\
\hline & Std. Deviation & 4,351 \\
\hline $\begin{array}{l}\text { Most Extreme } \\
\text { Differences }\end{array}$ & Absolute & ,076 \\
\hline & $\begin{array}{l}\text { Positive } \\
\text { Negative }\end{array}$ & $\begin{array}{l}, 076 \\
-, 069\end{array}$ \\
\hline $\begin{array}{l}\text { Test Statistic } \\
\text { Asymp. Sig. (2- } \\
\text { tailed) }\end{array}$ & & $\begin{array}{l}, 076 \\
, 087 \mathrm{c}\end{array}$ \\
\hline
\end{tabular}

Pada tabel 3 terlihat bahwa nilai taraf signifikansi atau nilai probalitas tests of normality Kolmogorov-Smirnov adalah 0,076. Nilai taraf signifikansi post-test lebih dari 0,05 , sehingga dapat disimpulkan bahwa distribusi data post-test adalah normal.

Setelah pengujian asumsi keparametrikan dan ternyata asumsi-asumsi tersebut terpenuhi, maka langkah selanjutnya adalah menganalisa data penelitian. Teknik analisis data yang digunakan adalah analisis varian dua jalur, yaitu faktorial $2 \times 2$ Analisis data tersebut pada hakekatnya digunakan untuk menguji tiga buah hipotesis penelitian. Ketiga hipotesis penelitian tersebut adalah sebagai berikut.

1) hasil belajar pebelajar berbeda secara signifikan jika diajar dengan menggunakan strategi pembelajaran kooperatif jigsaw dari pada strategi pembelajaran tradisional.

2) hasil belajar pebelajar yang memiliki keterampilan sosial tinggi berbeda secara signifikan dari pada pebelajar yang memiliki keterampilan sosial rendah.

3) ada interaksi antara strategi pembelajaran kooperatif jigsaw dan keterampilan sosial terhadap hasil belajar pebelajar.

Keterampilan sosial merupakan pendukung untuk meningkatkan hasil belajar. Arends, (2008) bahwa keterampilan sosial adalah perilaku-perilaku yang mendukung kesuksesan hubungan sosial dan meningkatkan individu untuk bekerjasama dengan orang lain secara efektif. Keterampilan sosial sangat dibutuhkan untuk hidup dan bekerjasama dibidang keterampilan berpartisipasi, dan keterampilan berkomunikasi. Dalam hal ini pembelajar dapat membantu pebelajar menguasai keterampilan-keterampilan antara lain keterampilan berbagi, yaitu membantu teman yang mengalami kesulitan untuk membagi waktu dan bahan-bahan yang akan dibagi untuk persiapan tugas-tugas pembelajaran.

Tabel 4 Hasil Analisis Varian Dua Jalur

Tests of Between-Subjects Effects Dependent Variable:HASIL BELAJAR

\begin{tabular}{llllll}
\hline Source & $\begin{array}{l}\text { Type III } \\
\text { Sum of } \\
\text { Squares }\end{array}$ & Df & $\begin{array}{l}\text { Mean } \\
\text { Square }\end{array}$ & F & Sig \\
\hline Corrected Model & $806,715 \mathrm{a}$ & 3 & 268,905 & 21,573 &, 00 \\
& 120213,8 & 1 & 120213,8 & 9644,03 & 0 \\
Intercept & 73 & & 73 & 6 & 0 \\
PEMBELAJAR & 219,581 & 1 & 219,581 & 17,616 &, 00 \\
AN & & & & & 0
\end{tabular}

Pengaruh Strategi...., -Abdul- || 26 


\begin{tabular}{lccccc} 
KSOSIAL & 92,357 & 1 & 92,357 & 7,409 &, 00 \\
& & & & & 7 \\
PEMBELAJAR & 67,011 & 1 & 67,011 & 5,376 &, 02 \\
AN ${ }^{*}$ & & & & & 2 \\
KSOSIAL & 1445,952 & 11 & 12,465 & & \\
Error & & 6 & & & \\
& 178586,0 & 12 & & & \\
Total & 00 & 0 & & \\
Corrected Total & 2252,667 & 11 & & \\
& & 9 & & \\
\hline
\end{tabular}

a. R Squared = ,358 (Adjusted R Squared = ,342)

Taraf signifikansi atau nilai probalitas strategi pembelajaran adalah 0,000 $(<0,05)$, maka hipotesis nol ditolak. Hal ini berarti bahwa "Hasil belajar pebelajar berbeda secara signifikan jika diajar dengan menggunakan strategi pembelajaran jigsaw dari pada strategi pembelajaran tradisional". Untuk mengetahui strategi pembelajaran mana yang memberikan pengaruh yang lebih beda, maka dilihat rerata (mean) pada statistik deskriptif berikut ini.

Tabel 5 Statistik Deskriptif Analisis Varian Dua Jalur

\begin{tabular}{|c|c|c|c|c|}
\hline Dependent Vari & $\begin{array}{l}\text { escriptive } \\
\text { le:HASII }\end{array}$ & $\begin{array}{l}\text { atisti } \\
\text { ELA. }\end{array}$ & & \\
\hline PEMBELAJARAN & $\begin{array}{l}\text { KATEGORI } \\
\text { SOSIAL }\end{array}$ & Mean & $\begin{array}{l}\text { Std. } \\
\text { Deviation }\end{array}$ & $\mathrm{N}$ \\
\hline TRADISIONAL & RENDAH & 35,30 & 3,576 & 50 \\
\hline & TINGGI & 39,30 & 3,302 & 10 \\
\hline & Total & 35,97 & 3,813 & 60 \\
\hline JIGSAW & RENDAH & 40,47 & 3,484 & 17 \\
\hline & TINGGI & 40,79 & 3,543 & 43 \\
\hline & Total & 40,70 & 3,500 & 60 \\
\hline Total & RENDAH & 36,61 & 4,192 & 67 \\
\hline & TINGGI & 40,51 & 3,517 & 53 \\
\hline & Total & 38,33 & 4,351 & 120 \\
\hline
\end{tabular}

Tabel 5 menunjukkan bahwa secara total rerata hasil belajar pebelajar pada penerapan strategi pembelajaran tradisional adalah 35,97 dan pada penerapan strategi pembelajaran jigsaw adalah 40,70. Hal itu berarti bahwa penerapan strategi pembelajaran jigsaw memberikan pengaruh yang lebih beda terhadap hasil belajar dibandingkan dengan penerapan strategi pembelajaran tradisional.

Berdasarkan tabel 4 juga dapat diketahui taraf signifikansi atau nilai probalitas keterampilan sosial, yaitu 0,007 (< $0,05)$. Dengan besaran nilai probalitas seperti itu, maka hipotesis nol ditolak. Hal ini berarti bahwa "Hasil belajar pebelajar yang memiliki keterampilan sosial tinggi berbeda secara signifikan dari pada pebelajar yang memiliki keterampilan sosial rendah".

Nilai taraf signifikansi atau nilai probalitas interaksi strategi pembelajaran dan keterampilan sosial adalah 0,007 $(<0,05)$. Oleh karena itu hipotesis nol ditolak. Hal itu berarti bahwa "ada pengaruh interaksi antara keterampilan sosial dengan strategi pembelajaran tradisional dan strategi pembelajaran jigsaw terhadap hasil belajar". Dengan kata lain, temuan penelitian ini yang menyatakan ada pengaruh interaksi antara strategi pembelajaran kooperatif dengan keterampilan sosial menguatkan temuan "ada perbedaan hasil belajar pebelajar yang diajar dengan strategi pembelajaran kooperatif yang berbeda".

\section{SIMPULAN \& SARAN Simpulan}

Berdasarkan deskripsi umum, pengujian hipotesis, dan pembahasan dapat disimpulkan beberapa kesimpulan hasil penelitian sebagai berikut.

1. terdapat perbedaan hasil belajar yang signifikan antara kelompok pebelajar yang menggunakan strategi pembelajaran jigsaw dengan kelompok pebelajar yang menggunakan pembelajaran tradisional. Hasil belajar dengan strategi pembelajaran jigsaw lebih efektif dibandingkan strategi pembelajaran tradisional.

2. terdapat perbedaan hasil belajar antara kelompok yang memiliki keterampilan sosial tinggi dengan kelompok pebelajar yang memiliki keterampilan sosial rendah. Tingkat keterampilan sosial tinggi hasil belajar lebih efektif dari pada keterampilan sosial rendah.

3. terdapat pengaruh interaksi yang signifikan antara implementasi strategi pembelajaran kooperatif tipe (jigsaw dan tradisional) dengan tingkat keterampilan sosial (tinggi dan rendah) terhadap hasil belajar. Aplikasi strategi pembelajaran 
tradisional dan jigsaw pada pebelajar dengan berketerampilan sosial tinggi, akan menghasilkan hasil belajar yang lebih efektif dan efisien dari pada berketerampilan sosial rendah.

\section{Saran}

Berdasarkan hasil penelitian tersebut dapat dikemukakan saran-saran yang terkait dengan pemanfaatan hasil penelitian dalam strategi pembelajaran kooperatif jigsaw dan keterampilan sosial dalam mata pelajaran Ilmu Pengetahuan Sosial (IPS) pada lembaga Sekolah Dasar sebagai berikut;

a) pembelajar IPS disarankan untuk meningkatkan hasil belajar pebelajar perlu menerapkan strategi pembelajaran kooperatif jigsaw dibandingkan tradisional dengan menggunakan strategi pembelajaran kooperatif karakteristik pebelajar akan lebih beda dengan cara; 1) merancang pembelajaran secara sistematis yang bersifat konstektual dengan memperhatikan karakteristik pebelajar (keterampilan sosial), sehingga pembelajaran dengan keterampilan komunikasi/bercakap-cakap, keterampilan bertanya/membuka diri, keterampilan menjawab, mengungkapkan perasaan dan keterampilan berbagi/merasakan perasaan orang lain dapat dilakukan dengan lancar, karena keterampilan sosial pebelajar memberikan pengaruh yang kuat dalam pencapaian hasil belajar pebelajar. 2) memahami keterampilan bekerjasama kelompok sebagai langkah memahami konsep materi pembelajaran. 3) pembelajar perlu memahani kepribadian dan karakteristik dan identitas, kemampuan dan pengalaman pebelajar masing-masing agar proses pembelajaran sesuai dengan kebutuhan potensi dan tujuan pembelajaran. Tidak semua strategi pembelajaran sesuai dengan materi, sehingga pembelajar harus mampu mengaitkan antara strategi pembelajaran, standar kompetensi dan kompetensi dasar. b). temuan penelitian dapat dimanfaatkan sebagai bahan masukan dan pertimbangan bagi pembelajar untuk dapat meningkatkan hasil belajar terutama pada pemahaman dan pengetahuan (kognitif) dan kepala sekolah dapat meningkatkan proses pembelajaran sesuai dengan tujuan pembelajaran.

c). konsep pembelajaran yang masih berpusat pembelajar (teacher centered instruction) pada sekarang sebaiknya harus berangsur-angsur bergeser dan mengalami perubahan konsep berpusat pada pebelajar (student centered instruction), peran pembelajar sebaiknya hanya sebagai perancang, fasilitator, dan motivator pembelajaran dengan difasilitasi sumbersumber belajar yang riil (nyata) sesuai dengan lingkungan kehidupan pebelajar sehari-hari.

d). dalam penelitian ini, jika dilihat dari keefektifan dalam pencapaian kriteria keberhasilan, hasil belajar belum optimal, maka perlu dilakukan kajian lebih lanjut dengan meningkatkan kualitas pembelajaran berupa penelitian tindakan kelas. Melalui penelitian tindakan kelas dimungkinkan dapat menemukan proses dan keefektifan penerapan startegi pembelajaran kooperatif tipe jigsaw, sehingga pencapaian hasil belajar dapat optimal sesuai dengan tujuan pembelajaran.

e). perangkat pembelajaran yang digunakan dalam penelitian ini, meliputi; silabus, RPP/skenario pembelajaran, bahan ajar, LKS dikembangkan berdasarkan kurikulum panduan KTSP (BNSP, 2006) dengan memperhatikan karakteristik pebelajar dan kondisi sekolah, agar penerapan strategi pembelajaran kooperatif tipe jigsaw dapat berjalan secara optimal.

f). variabel terikat yang diteliti pada penelitian ini hanya pada aspek kognitif, untuk itu diperlukan penelitian hasil belajar yan meliputi aspek afektif dan psikhomotor, dan yang sejenisnya. 


\section{DAFTAR RUJUKAN}

Arikunto, S. 2003. Dasar-dasar Evaluasi Pendidikan, Jakarta: Bumi Aksara

Aronson, A. 2009. Jigsaw Classroom, www, Jigsaw. Org/overview, inter. Diakses 29 Desember 2009

Arends, R. I., 2007, Learning to Teach, seventh edition, New York; McGraw Hill Companies, Inc 1221 Avenuce of the Americas

Arends, R. I., 2008. Learning to Teach, seventh edition, New York; McGraw Hill Companies, Inc., 1221 Avenue of the Americas.

Bandura, A. 1977. Social Learning Theory. Englewood Cliffs, NJ: PrenticeHall

Brooks, J.G. \& Brooks, M.G., (1993) The Case For Construtivist Cllassroom Alexandria,VA;AssociationforSup ervision and Curriculum Development

Cohen, E. G. 1994. Restructuring The Cllasroom Condition for Production Smail Group Review of Educational Research, 64(1),pp,01-35

Degeng, I. N. S. 1989, Kerangka Perkuliahan dan Bahan Pengajaran. Jakarta; Proyek Pengembangan Lembaga Pendidikan Tenaga Kependidikan.

Degeng, I. N. S. 2001. Kumpulan Bahan Pembelajaran, Menuju Pribadi Unggul lewat Perbaikan Kualitas Pembelajaran di Perguruan Tinggi Malang: UM - LP 3

Depdiknas, 2006. Peraturan Menteri Pendidikan Naional RI no.22

29 || JINOTEP, Volume 3, Nomor 1, Oktober 2016 tahun 2006 tentang Standar Isi Untuk Satuan Pendidikan Dasar dan Menengah, Jakarta: Depdiknas.

Eggen, P. \& Kauchak, D. 2007. Educational Psychology, Windows on Classroom, Sevent Edition. Columbus Ohio: Pearson Merril Practice Hill

Gagne, R. M. 1985. The Condition of Learning (4 rd ed) New York; Holt, Rinehart \& Winston

Gredler, \& Margaret, E. 1991. Learning and Instruction Theory into Practice. Diterjemahkan Prof. Dr. Munandir, MA. Jakarta; CV. Rajawali

Johnson, A. 2006. Chemical education researh in Glasgow in perspective, Chemical Education Research and Practice, 7(3), 49-63

Merrel, K. W. \& Gimpel, G. A. 1998. Social skill of children and adolescents; conceptualication, assessment, treatment. Mahwah, $\mathrm{Nj}$; Lawrence Eribaum Associates,inc

Moore, K. D. 2005. Effective Instructional Strategies, from theory to pratice . Hernderson : Henderson State University

Oliver, K. \& Hannafin, M. 2001. Developing and Refining Mental Model in Open-ended Learning Environment : A case study. Educational Research and Development. 49(4), 5-32

Piaget, J. 1963. The Origins of Intelligence In Children. New York: International Universities Press. 
Pratisto, A. 2004. Cara Mudah Mengatasi Masalah Statistik dan Rancangan Percobaan dengan SPSS 12. Jakarta:PT Elex Media Komputindo

Reigeluth, C. M. 1999. Instructional Design Theories and Models. Volume II. A. New York Paradigma of Instructional Theory. Lawrence Erlbaum Associates, New Jersey and London: Publishers, Marwah

Riggio, R. E. \& Reichard, R. J. 2008. "The emotional and social intelegences of effective leadership". Journal of, Managerial Psychology, 23 (2), P. 171.

Sagala, S. 2007. Konsep dan Makna Pembelajaran. Bandung: Alfabeta.

Samsuddin, H. \& Maryani E. 2008. Pengembangan program pembelajaran IPS untuk meningkatkan kompetensi ketrampilan sosial makalah seminar Nasional Makasar.

Sapriya, 2011. Pendidikan IPS, Jakarta: Remaja Rosdakarya

Sardiman, A. M. 2004. Interaksi dan Motivasi Belajar Mengajar. Jakarta: PT Raja Grafindo Persada

Sharan, Y. \& Sharan, S. 1992. Expanding Cooperative Learning Through Group Onvertigation. New York: Teacher College Press

Slavin, R. E. 1995. Cooperative Learning theory, and Practive, Jew Jersey: Prentice Hall
Slavin, R. E. 2000. Educational Psychology, Theory and Practice edition VII Boston: Allymand Bacon

Slavin, R. E. 2008. Cooperative Learning , teori , riset dan Praktik, terjemahan Nurulita cetak III Bandung , Penerbit Nusamed Studio

Soemantri, M. N. 2001. Menggagas Pembaharuan Pendidikan IPS. Bandung; Rosda Karya

Suhirman, 2008. Pengaruh Metode Pembelajaran Kooperatif dan Ketrampilan Sosial terhadap Perolehan Belajar dan Sikap Sosial pada siswa Sekolah Dasar kelas $V$. Disertasi. Malang: PPS Universitas Negeri Malang.

Suryabrata, S. 2003. Metodologi Penelitian, Jakarta: PT Rajagrafindo Persada.

Tuckman, B. W. 1999. Conducting Educational Research, Fifth edition. New York: Harcourt Brace College Publishers

Uno, H. B. 2008. Model Pembelajaran, Menciptakan Proses Belajar Mengajar yang Kreatif dan Efektif . Jakarta. Bumi Aksara

Winataputra, U. S. 1993. Strategi Belajar Mengajar IPA, Jakarta, Universitas Terbuka.

Welton, D. A. \& Mallan, J. T. 1988. Children and Their World (terjemahan). Boston: Houghton Mifflin Co. 